\title{
STRATEGIC RESONANCE AND INNOVATION IN PUBLIC SECURITY SERVICES IN BRAZIL
}

\author{
Ressonância estratégica e inovação em serviço de segurança pública no Brasil
}

\author{
Sueli Menelau* \\ Luiz Akutsu** \\ Antônio Isidro-Filho*** \\ Antônio Sérgio Araújo Fernandes $* * *$
}

\section{ABSTRACT}

The aim of this study was to test an exploratory contribution of a model for the relationship between strategic resonance (SR) and innovation in public security services (IPSS), with the construction of two scales. The subject of this analysis are the Federal District Military Police (PMDF) and Community Security Stations (CSSs). The model for the relationship was tested using structural equation modeling (SEM) of innovation in public security services (IPSS) and strategic resonance (SR) explanatory variables. The results show that the structural relationships postulated between the variables are corroborated by the global sample analyses, obtaining evidence of scale validation. We concluded that the CSSs are an IPSS, where we observed that policing is linked to interactions between the population and PMDF in a relationship comprising the human, structural and operational characteristics of the service. The main contributions of this research are the proposal of a relationship between SR and IPSS and the development and validation of two scales that measure these two constructs.

Keywords: Innovation in public security services. Strategic resonance. Military police. Community security stations. Structural equation modeling.

\section{RESUMO}

O objetivo do estudo foi testar, com a construção de duas escalas, uma contribuição exploratória de um modelo da relação entre ressonância estratégica (RE) e inovação em serviço de segurança pública (ISSP). O objeto de análise são os Postos Comunitários de Segurança (PCSs) da Polícia Militar do Distrito Federal (PMDF). O modelo da relação foi testado utilizando structural equation modeling de variáveis explicativas de ISSP e RE. Os resultados mostram que as relações estruturais postuladas entre as variáveis são corroboradas pelas análises da amostra global, obtendo-se evidências de validação das escalas. Conclui-se que os PCSs são uma ISSP na qual é possível perceber que o policiamento está atrelado às interações entre população e PMDF, em uma relação composta por características humanas, estruturais e operacionais do serviço. Destacam-se como principais contribuições desta pesquisa a proposição da relação entre $R E$ e ISSP e o desenvolvimento e a validação de duas escalas que medem esses dois constructos.

Palavras-chave: Inovação em serviço de segurança pública. Ressonância estratégica. Polícia militar. Postos comunitários de segurança. Modelagem de equação estrutural.

\footnotetext{
* Professor of the Management Nucleus of the Universidade Federal de Pernambuco (UFPE). Coordinator of the Professional Master's Degree in Intellectual Property, Technology Transfer for Innovation (ProfNIT) and LabPOP of the Universidade Federal de Pernambuco (UFPE). PhD in Administration by the the Universidade de Brasília (UnB). Email: suelimenelau@gmail.com. ORCID: 0000-0002-5479-7292

** Federal Auditor of External Control of the Federal Court Accounts. PhD in Administration by the Universidade de Brasília (UnB). Email: luiz_akutsu@yahoo.com.br. ORCID: 0000-0001-6581-5460

*** Professor of the Postgraduate Program in Administration of the Universidade de Brasília (PPGA/UnB) and Coordinator of LineGov of the Universidade de Brasília (UnB). PhD in Administration by the Universidade de Brasília. Email: antonio.isidro.filho@gmail.com. ORCID: 0000-0003-1174-8586

**** Professor of the Graduate Nucleus of Administration of the Universidade Federal of Bahia (NPGA/UFBA). $\mathrm{PhD}$ in Political Science from the Universidade de São Paulo (USP), Postdoctoral Degree from the University of Texas at Austin at the LBJ School of Public Affairs. Email: antoniosaf@ufba.br. ORCID: 0000-0002-4171-7759
} 


\section{INTRODUCTION}

n order to design and provide public services, public organizations often need to strategically associate organizational and environmental factors, altering their characteristics through innovations and the effects can be evaluated by their performance (CHOI; CHANG, 2009; NARANJO-GIL, 2009). Operating and innovating strategically is a considerable challenge for organizations that work in the public sector (LEONARD-BARTON, 1982), particularly those providing public security services (ROLIM, 2007). Following a bibliographical research on articles published between January 2001 and December 2015, using the keyword "public security" on the SciELO and Spell databases, we verified that the field of studies on public security has been increasing in Brazil. However, Adorno and Dias (2014) and Lima, Ratton and Azevedo (2014) highlight that this area of study lacks academic contributions on some of its nuances, including discussions about public security policies, to impose regulation in a country affected by an increase in police violence during the same period. Cruz and Barbosa (2002a), Sapori (2002) and Lima, Ratton and Azevedo (2014) add that public security services provided by military organizations are not generally studied through an organizational approach, despite the importance of obtaining innovation in services (IS) provided by the Brazilian Criminal Justice System (formed by the judicial and prison system, Public Prosecution Service (MP) and police institutions), which are responsible for the State's exclusive activity of maintaining public order. While a number of studies have focused on institutional-political innovation, which involves public police organizations - a valuable contribution - however, public management literature has shortcomings, regarding the analysis of these institutions (CRUZ; BARBOSA, 2002a; LIMA; RATTON; AZEVEDO, 2014).

Research on innovation in public security services (ISSP) and specifically about policing, generally focuses on IS, whether at an institutional (for example, BEATO FILHO, 1999; CRAIG; HEIKKILA, 1989) or individual level (see MESQUITA NETO, 2004), instead of an organizational level. In addition, studies tend to emphasize innovations in policing (OLIVEIRA JÚNIOR; SILVA, 2010) and governance models (CHALOM et al., 2001; PONCIONI, 2013), instead of the processes through which innovation is implemented. Research has also suggested (see ROBERTSON, 1998; MARX, 1987; SPARROW, 2014) that the specific characteristics of public security services make the innovation process in organizations in the public sector distinct from what occurs in the private sector. McKenna (2014) highlights that studies in the field of public security do not consider that the functional characteristics of police services are affected in the process of adding value. Bayley and Skolnick (2002) and Coelho (1986) add that studies on the topic rarely connect aligning the environment with the function of police organizations' operations as a strategic contributor to developing and maintaining IS, therefore, it constitutes a disjunction between police apparatus and administration.

In research discussions held in the organizational context that emphasize innovation as an important strategic concept, also for public sector organizations (see MULGAN; ALBURY, 2003 for example), the integrated innovation approach (DJELLAL; GALLOUJ, 2012a; 2012b) and parameters for studies performed at private sector organizations are predominantly used. The central position of this approach is that the product innovation process (which can be goods or services) develops by altering its generic functional cha- 
racteristics and is centered on the user-provider relationship (GALLOUJ, 1994; 2002; 2007). Many of the authors who perform research on the topic highlight the importance of aspects common to goods and services in the innovation process and develop typologies of the forms of innovation by mobilizing the characteristics of the product resulting from the process (VARGAS et al., 2013). Innovation is considered a complement to the traditional product perspective, having a comprehensive and multidimensional concept that involves various functions, both within and outside the organization (CARLBORG; KINDSTRÖM; KOWALKOWSKI, 2014). Technological and non-technological aspects and characteristics that distinguish the majority of product services (such as inseparability between production and consumption, intangibility, low negotiability and heterogeneity) are seen as an important condition that adds value to the process (GALLOUJ; SAVONA, 2010; GALLOUJ; WINDRUM, 2009).

In view of the aim of this study, a further important premise is the influence that organizational alignment, both with the environment and company resources and processes, exercises on the establishment of an organization's course of action, affecting its innovations. Seen in these terms, guaranteeing continuous connections and harmonization between the environment and the organization's operational capacities, between these capacities and corporate strategy and between all the functions and all of the organizational levels are seen as a crucial factor to find strategic resonance (SR) (BROWN, 2000). For Brown and Cousins (2004) and Wang and Cao (2008), the operational plant and transformation of organizational design into a less bureaucratic structure are also seen as relevant and effective to promote SR.

Investigations into SR have focused on understanding the processes under the auspices of the industrial manufacturing paradigm (see NAQSHBANDI; KAUR, 2011) and, in general, have concentrated on activities in the car industry (BROWN, 2000; BROWN; BESSANT, 2003). Although there is little empirical evidence, we observed that SR is fundamental to innovation (BROWN, 2001) and a sustainable strategy (SPETIC; MARQUEZ; KOZAK, 2012).

In other countries, experiments which include a process of organizational reform of police forces provide them with methods to solve problems (instead of a response to criminal occurrences) and go back at least 60 years in History. Examples are those conducted by the United States police between the 1950s and 1990s (RIBEIRO, 2014). However, in Brazil, a lack of experience in implementing public security prevention policies (SILVEIRA, 2014) means that the actions taken by the police differ significantly (RIBEIRO, 2014); have not been incorporated by state corporations; while focusing solely on the Federal District and a further five Brazilian states from a total of 27 (BONDARUK; SOUZA, 2012). With regards to the Federal District Military Police's (PMDF) trajectory since 1995, the organization has been intermittently seeking to offer a community policing (CP) service by creating councils, patrols and attempts to form a closer relationship with the population (see GDF, 2005; PMDF, 2007 and UNODC, 2011).

With this scope in mind, the CP service, was considered a policing IS and a new organizational strategyd, established through a partnership between the Military Police (PM) and the population who started taking part in preparing actions to preserve public and civil order (BRODEUR, 2002; GAINES; TROJANOWICZ; KAPPELER, 2009; MENELAU et al., 
2015). The dynamics take place through ostensive and preventive police work corresponding to the complex exercise of law reenforcement defined by an inalienable commitment to the social construction of peace and well-being and respect for human rights. Therefore, this work has the general objective of demonstrating the influence that SR may have on ISSP, taking the PMDF Community Security Stations (CSSs) as a case study. As an additional contribution to literature in the area and field of policing, it provides the construction of two scales that measure both SR and innovation in the police service. With this purpose, this article is structured in three sections, in addition to this introduction and a conclusion section. Section 2 approaches the concepts of SR and ISSP; section 3 describes the case of the PMDF CSSs and presents the procedures to develop the adopted model, through the Structural Equation Modeling (SEM) method, and section 4 presents the results of the analysis of the relationship between SR and ISSP in this specific case.

\section{STRATEGIC RESONANCE AND INNOVATION IN PUBLIC SECURITY SERVICES}

On the understanding that in order to add value to the service, mobilizing internal-external competencies and internal-external technical characteristics (material/immaterial) is required, the focus of this research is at the meso-level of analysis, studying the sub-units of the organization that provides this service (WAGNER III; HOLLENBECK, 2012). Therefore, the construction is based on the integrated approach to innovation initially proposed by Gallouj and contributors (DJELLAL; GALLOUJ, 2012a, 2012b; GALLOUJ, 2002; GALLOUJ; WEINSTEIN, 1997) and the SR approach developed by Brown and contributors (BROWN, 2000; BROWN; BLACKMON, 2005; BROWN; FAI, 2006). Thus, the focus of attention is on the operational level of the organization that directly contributes to providing the service (BAYLEY; SKOLNICK, 2002). In the model proposed, competencies and technical characteristics (of providers and users) influence or are influenced by the organization's operational functions, the strategic alignment within them and the environment in which they operate are observed as functional vectors.

In order to explain the addition, subtraction, association, dissociation or formatting of different changes in an innovation (DJELLAL; GALLOUJ, 2012b; GALLOUJ, 2002) in public security, at times researchers have concentrated on the perspective of police officers at the strategic center (SPARROW, 2014) and, at others, visualize innovation, while focusing on the environment and the way it reflects on the institutional context (such as in BEATO FILHO, 1999; CRUZ; BARBOSA, 2002a, 2002b). In this research, these features of police service operations are examined, according to the characteristic vectors which form them, as described by Gallouj and Weinstein (1997), and enhanced for the public area by Djellal and Gallouj (2012b). Thus, competencies should be understood as ways of processing knowledge, while the technical characteristics include the operations which converge to accomplish the service (GALLOUJ, 2002).

On considering the innovation process in the public sector, there are gaps in research both from the aspect of an analysis of the process and the importance of the external environment for strategies that lead public organizations towards innovation (DE VRIES; BEKKERS; TUMMERS, 2014). According to Lima and Vargas (2012), these gaps are due to innovations by public sector organizations and have specific features that are not present in 
the other organizations operating in environments where capital is present. The way public service providing organizations manage their relationships with the environment, strategically resonating, is one of the important precedents for the competencies and technical characteristics of the operational innovation process (BROWN, 2000; BROWN; FAI, 2006; COUSINS; STANWIX, 2001).

SR should be sought through a decentralized, bottom-up process, in which alignment of the operational levels and the environment, with the formulation of corporate strategy, is identified as significant to the high performance of operations (BROWN, 2000). Internally, the main mechanisms which contribute to the SR process are: (i) identifying and developing the qualification of operations, particularly central competencies related to people, processes, products and relationships; (ii) improving the consistency of corporate management decisions in relation to the competencies of operations in the strategic process and (iii) improving involvement and managerial influence on operations in the strategic process (BROWN; BLACKMON, 2005; BROWN; FAI, 2006). Factors, such as the decision to invest in structure, fragmented demands, speed of delivery and flexibility have an influence on adapting the optimum performance of operations to the environment (BROWN, 2000; SLACK; LEWIS, 2011). Therefore, there is an imperative need, along with the organization's need based to align its strategies on its resources with the environment.

Integration and a balance of the organization's two types of interest lead to what Brown and Blackmon (2005) establish as strategic flexibility. Of equal importance to the innovation process is the search to align their operations with environmental needs, which Brown (2000) classifies as SR. This perspective is also shared by Slack and Lewis (2011), for whom operations should be conditioned to the understanding of the environment that the organization has. As a rule, the environment and resources are central elements of classic studies about the strategy that leads to innovation (BROWN; FAI, 2006; MINTZBERG; LAMPEL; GHOSHAL, 2006). In the field of public administration, recent studies about police organizations have suggested that the introduction of innovations may be affected by the environment and operational characteristics. For example, Cruz and Barbosa (2002a) and Oliveira (2011) argue that the bureaucratic organizational structure that characterizes police organizations influences the implementation of innovation. Craig and Heikkila (1989) and Rolim (2007) concentrated on how complex policy and the environment come into play during the ISSP process. Therefore, the specific characteristics of public police organizations (BAYLEY; SKOLNICK, 2002) may influence the SR desired during the innovation process (see MESQUITA NETO, 2004; OLIVEIRA JÚNIOR; SILVA, 2010).

The argument proposed here is that the role of SR is fundamental to the incidence of ISSP. Figure 1 presents the main latent variables (also called non-observable variables, constructs or factors) of the theoretical framework of this research. It is expected that SR has a direct effect on IS which, in turn, is the set of vectors that represent the CP service. Earlier studies suggest that innovation can be achieved by avoiding conflicting demands between the three factorswhich predict SR (strategic decision-making, environmental demands and operational capacities) (BROWN; BLACKMON, 2005). Consequently, SR can also directly contribute to the creation of less bureaucratic, decentralized and more agile organizational structures, encouraging new attitudes from members of the organization and redirecting the operations undertaken (BROWN, 2000). Therefore, the specific context of police organiza- 
tions influences the implementation of ISSP, while encouraging (or restricting) the behavior of the organization's operational level.

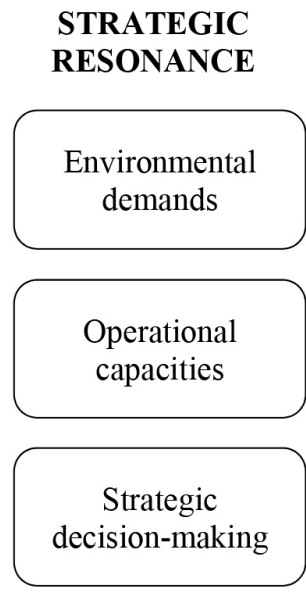

\section{INNOVATION IN \\ PUBLIC SECURITY SERVICES}

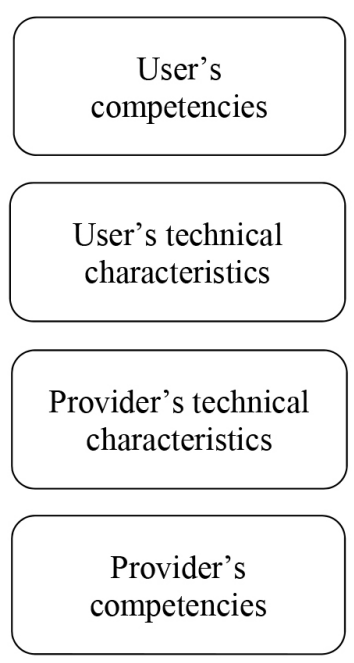

Figure 1 - Relation between strategic resonance and innovation in public security services.

\section{RESEARCH PROCEDURES}

The research was carried out in 2015 and the Federal District CSSs were the unit of analysis. In order to analyze the relationship between IS and SR at the PMDF and to study the existence and magnitude of the targeted variables, quantitative (BREWER; HUNTER, 2006), exploratory, descriptive (CHURCHILL, 1999) and cross-sectional (MALHOTRA, 2001) research was conducted. Primary data was obtained through a face-to-face survey of a sample of military police who provide a CP service at the CSSs.

\subsection{SUBJECT OF THE STUDY: COMMUNITY SECURITY STATIONS}

The PMDF is a Brazilian public organization and component of the national judicial system. It is present in all the 33 Federal District administrative regions (RA/DF), through 45 units with responsibility for the area - Military Police Battalions (BPM) - and a regiment that was definitively established in 1966. The PMDF is the public security organization responsible for an ostensive policing service and preservation of public order in the Federal district (DF) and, additionally, it serves as an auxiliary force and reserve for the country's army. The organization obtained international acknowledgement for its CSS program, which emerged from a governmental proposal for public security, aiming to establish 300 police stations with this nomenclature (MENELAU et al., 2015). 
A CSS is a physical unit of public community equipment, designed to serve as base-stations of public security officials and to assist the community, guaranteeing security and acting as a reference point in situations of imminent risk, various emergencies or the need to mediate conflicts (PMDF, 2007). These stations are not merely physical installations to isolate the police from the community in which they operate but, conversely, are a location for support and proximity between the State (represented by public security) and the population (UNODC, 2011). Currently there are 75 CSSs, which are hierarchically dependent (for management and support) on a BPM and housed by the administrative regions (RA/DF).

The relationship between the police and the community (CARDOSO, 2011) can be evaluated through the CSS. The innovation of the CSS in the PMDF comprises the organization providing a CP service in co-production with the population, identifying, prioritizing and solving problems, which are not solely restricted to crime, and may involve fear resulting from insecurity in the community, among other aspects that affect public security (PMDF, 2007). Thus, the CSSs can be considered innovations in the approach of type II (process) described by Schumpeter (1982) and the premises of the Organization for Economic Cooperation and Development (OECD, 2005), since implementation stems from a significant change in the way the PMDF operates in the services it provides (MENELAU et al., 2015).

\subsection{THE POPULATION, SAMPLE AND DATA COLLECTION AND ANALYSIS PROCEDURES}

The sample is probabilistic (FORMIGA, 2011) since the collection was carried out in all the DF CSSs, highlighting that the respondents consulted were willing participants, with anonymity assured for their responses. Interviewee segmentation was used, in order to limit geo-demographic biases, guided by the following parameters: (i) respondent selection (a range of positions and ranks in the PMDF was sought); (ii) location to apply the questionnaire (place of work and at various RA/DF) and (iii) the time span (applied in a 45-day period, enabling ample collection). Six-hundred and three (603) completed questionnaires were obtained from 1,360 police officers allocated to the CSSs (44.34\%), being in junior positions (sub-lieutenant, first, second and third sergeant, corporal, private and second-class private) and managerial officials (first and second lieutenants).

There were a number of reductions due to the absence of data (the interviewees did not complete $50 \%$ of the items). The frequency analysis, Missing Values Analyses (MVA) and distribution of missing data demonstrated that the percentage of these values (questionnaires with missing data) was less than $5 \%(2.5 \%)$ and an analysis of the correlation of missing values showed that they were randomly distributed (HAIR et al., 2009; TABACHNICK; FIDELL, 2007). These observations were then excluded, with 588 valid observations remaining in the sample, in which there was no missing data, in line with Marôco (2010), who evaluates that between 10 and 15 observations per presented variable is sufficient.

In order to explain the inter-relationships between the main variables, the study used the Structural Equation Modeling - SEM method (MARÔCO, 2010). This approach was considered advantageous, as opposed to a multiple linear regression, since it can simultaneously evaluate the influence of multiple independent variables in dependent multiple variables, as well as considering the theory to define the items for each factor (MARÔCO, 2010). This is possible because SEM presents adjustment indicators which enable an objec- 
tive decision about the validity of the construct of the measure analyzed, compared with the other scales explored (FORMIGA, 2011). By using SEM, the whole model could be tested instead of the separate relationships. Modeling was used to test to which point the proposed theoretical framework adjusts to the data (MARÔCO, 2010) and, consequently, the extent to which it can function as an explanatory framework for the relationship between SR and ISSP.

\subsection{MEASURES}

The research instrument is subdivided into two scales. The first, with 25 items, corresponds to the ISSP measurement and comprises four factors which characterize IS for the policing context. The second scale corresponds to 18 items (also called observable variables) which measure the SR construct. This scale seeks to evaluate the degree of agreement for each subject, with respect to the strategic alignment between PMDF and CSSs, measuring: environmental demands, decision-making and operational capacities. Both are organized in a 10 -point Likert scale, varying from $1=$ totally disagree to $10=$ totally agree. A qualitative stage was carried out separately for the scales (to construct the items) for content analysis (BARDIN, 2009) and complied with its theoretical formation (see MENELAU, 2015). Exploratory factor analysis (EFA) and confirmatory factor analysis (CFA) were then carried out, in accordance with Marôco (2010).

Table 1 displays a description of the factors prepared in the qualitative stage and the items that subsequently formed the questionnaire.

Table 1 - Factors of analysis and questionnaire items

\begin{tabular}{|c|c|c|c|}
\hline Factor & Description & Scope & Item \\
\hline \multirow{8}{*}{$\begin{array}{l}\text { Provider's } \\
\text { technical } \\
\text { characteris- } \\
\text { tics }\end{array}$} & \multirow{8}{*}{$\begin{array}{l}\text { Instruments used } \\
\text { (as methods and } \\
\text { technologies) to } \\
\text { operationalize } \\
\text { the process of } \\
\text { providing the CP } \\
\text { service at the } \\
\text { CSSs. }\end{array}$} & \multirow{8}{*}{$\begin{array}{l}\text { Include knowledge } \\
\text { and routines of the } \\
\text { CSSs }\end{array}$} & $\begin{array}{l}\text { - The availability of vehicles is compatible with doing } \\
\text { my job. }\end{array}$ \\
\hline & & & $\begin{array}{l}\text { - The physical structure of my place of work is } \\
\text { adequate to perform my activities. }\end{array}$ \\
\hline & & & $\begin{array}{l}\text { - The number of police officers in my unit of work is } \\
\text { adequate to perform community policing activities. }\end{array}$ \\
\hline & & & $\begin{array}{l}\text { - The use of foot patrol policing (POG) contributes } \\
\text { towards improving the PMDF service. }\end{array}$ \\
\hline & & & $\begin{array}{l}\text { - The PMDF channel of communication allows me to } \\
\text { consult and receive information pertinent to my job. }\end{array}$ \\
\hline & & & $\begin{array}{l}\text { - The stock of personal protective equipment (bulle- } \\
\text { t-proof vest and arms, among others) is compatible } \\
\text { with the number of police officers at my place of } \\
\text { work. }\end{array}$ \\
\hline & & & $\begin{array}{l}\text { - The consumable materials (office and cleaning } \\
\text { materials, among others) provided by the PMDF are } \\
\text { sufficient for my place of work to operate. }\end{array}$ \\
\hline & & & $\begin{array}{l}\text { - The service support materials (such as cones, } \\
\text { radios, transceivers and computers, etc.) provided } \\
\text { by the PMDF are sufficient for my unit of work to } \\
\text { operate. }\end{array}$ \\
\hline
\end{tabular}




\begin{tabular}{|c|c|c|c|}
\hline Factor & Description & Scope & Item \\
\hline \multirow{9}{*}{$\begin{array}{l}\text { Provider's } \\
\text { competen- } \\
\text { cies }\end{array}$} & \multirow{9}{*}{$\begin{array}{l}\text { Procedures to } \\
\text { process the } \\
\text { knowledge of the } \\
\text { police (or PMDF) } \\
\text { who provide the } \\
\text { CP service at the } \\
\text { CSSs, can be } \\
\text { acquired through } \\
\text { experience, } \\
\text { routines and } \\
\text { organizational } \\
\text { learning }\end{array}$} & \multirow{9}{*}{$\begin{array}{l}\text { Include knowledge } \\
\text { and routines of the } \\
\text { CSSs }\end{array}$} & $\begin{array}{l}\text { - The daily actions of my work with community } \\
\text { policing enable the construction of trust in the } \\
\text { community. }\end{array}$ \\
\hline & & & $\begin{array}{l}\text { - Social actions (talks and courses, etc.) held by the } \\
\text { PMDF for the community provide skills to perform my } \\
\text { job. }\end{array}$ \\
\hline & & & $\begin{array}{l}\text { - The contributions of my job are related to the } \\
\text { improvement of the PMDF service. }\end{array}$ \\
\hline & & & $\begin{array}{l}\text { - The information obtained from my work colleagues } \\
\text { favor the acquisition of knowledge about my commu- } \\
\text { nity policing work routine. }\end{array}$ \\
\hline & & & $\begin{array}{l}\text { - The training course contributed towards performing } \\
\text { my community policing activities. }\end{array}$ \\
\hline & & & $\begin{array}{l}\text { - Community policing favors friendliness in rela- } \\
\text { tionships between PMDF police. }\end{array}$ \\
\hline & & & $\begin{array}{l}\text { - The data obtained from local residents (nearby } \\
\text { community) facilitates performing my job. }\end{array}$ \\
\hline & & & $\begin{array}{l}\text { - The PMDF manuals and regulations orientate the } \\
\text { actions in my community policing routine. }\end{array}$ \\
\hline & & & $\begin{array}{l}\text { - The training held at the PMDF contributed towards } \\
\text { acquiring new knowledge and skills to perform my } \\
\text { community policing activities. }\end{array}$ \\
\hline \multirow{4}{*}{$\begin{array}{l}\text { User's } \\
\text { technical } \\
\text { characteris- } \\
\text { tics }\end{array}$} & \multirow{4}{*}{$\begin{array}{l}\text { Devices used (as } \\
\text { procedures and } \\
\text { technologies) to } \\
\text { operationalize } \\
\text { the process of } \\
\text { providing the CP } \\
\text { service at the RA/ } \\
\text { DF of the CSSs }\end{array}$} & \multirow{8}{*}{$\begin{array}{l}\text { Cover the know- } \\
\text { ledge and routines } \\
\text { of the population } \\
\text { served by the CSSs }\end{array}$} & $\begin{array}{l}\text { - The community is organized in social networks to } \\
\text { increase security in the region. }\end{array}$ \\
\hline & & & $\begin{array}{l}\text { - The presence of community policing reduces the } \\
\text { construction of security resources (such as bars and } \\
\text { the height of walls etc.) in community housing. }\end{array}$ \\
\hline & & & $\begin{array}{l}\text { - The presence of community policing reduces the } \\
\text { installation of security resources (such as electric } \\
\text { fences and video cameras) in community housing. }\end{array}$ \\
\hline & & & $\begin{array}{l}\text { - The presence of community policing reduces the } \\
\text { employment of private surveillance services by the } \\
\text { community. }\end{array}$ \\
\hline \multirow{4}{*}{$\begin{array}{l}\text { User's com- } \\
\text { petencies }\end{array}$} & \multirow{4}{*}{$\begin{array}{l}\text { The result of CP } \\
\text { activities (talks } \\
\text { and courses etc.), } \\
\text { represent the } \\
\text { knowledge and } \\
\text { skills acquired by } \\
\text { the population or } \\
\text { individual assisted }\end{array}$} & & $\begin{array}{l}\text { - The social actions performed by the PMDF have } \\
\text { developed new security skills in the community. }\end{array}$ \\
\hline & & & $\begin{array}{l}\text { - The social actions performed by the PMDF enabled } \\
\text { the multiplication of new social actions organized by } \\
\text { society. }\end{array}$ \\
\hline & & & $\begin{array}{l}\text { - My work activities facilitate the emergence of } \\
\text { new behavior to prevent crimes by members of the } \\
\text { population. }\end{array}$ \\
\hline & & & $\begin{array}{l}\text { - My routine actions enable the construction of the } \\
\text { community's trust in the PMDF's work. }\end{array}$ \\
\hline
\end{tabular}




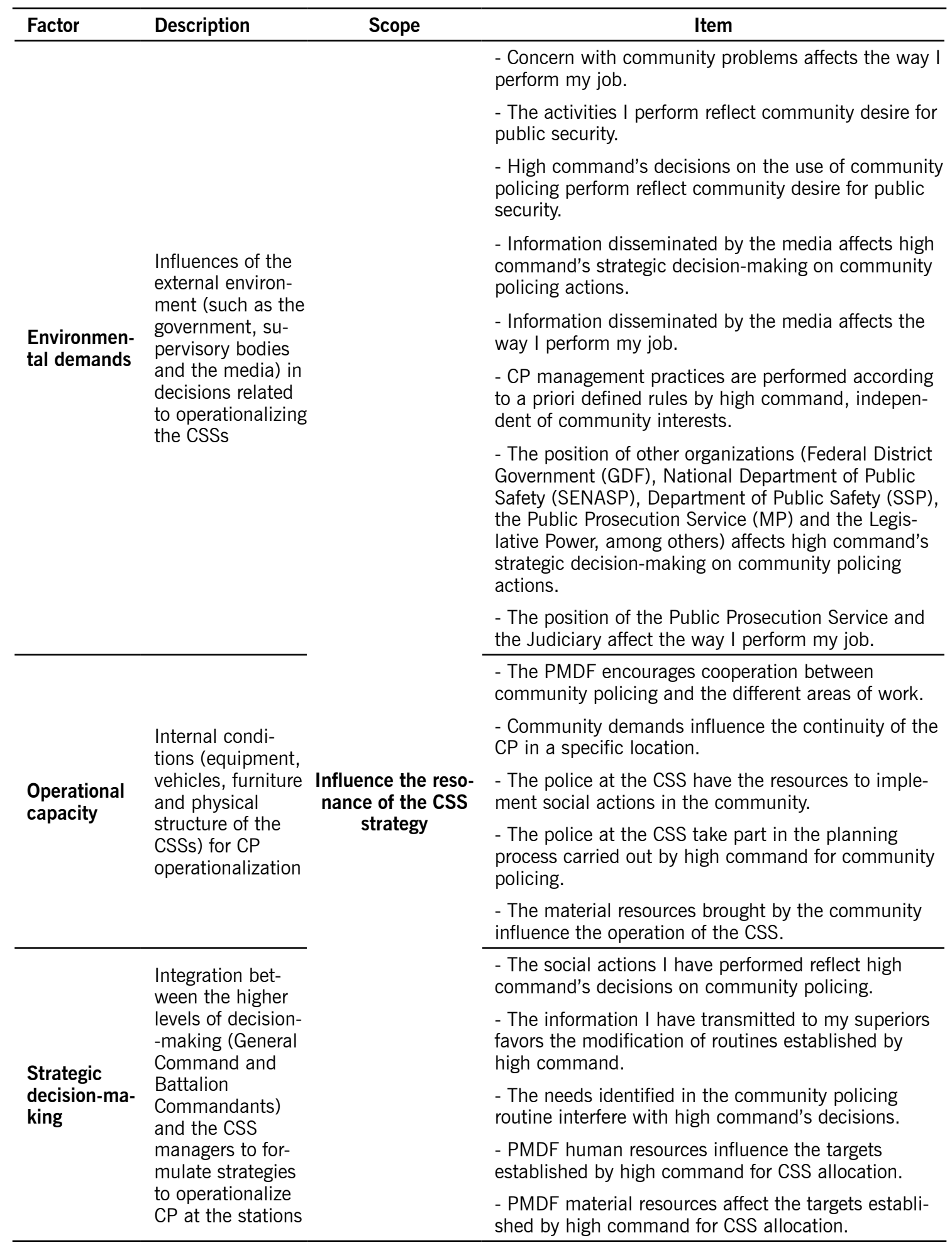

The SR scale factors were made up of the following items: environmental demands, operational capacity and strategic decision-making. The ISSP scale is formed by the following factors: provider's technical characteristics, user's technical characteristics, provider's 
competencies and user's competencies. The items were grouped together as the exploratory stage suggested and factor organization took place as demonstrated in Table 2:

Table 2 - Factor organization

\begin{tabular}{lccccccc}
\hline Scale & \multicolumn{3}{c}{ ISSP } & \multicolumn{3}{c}{ SR } \\
\hline Factors & $\begin{array}{c}\text { User's } \\
\text { technical } \\
\text { characteristics }\end{array}$ & $\begin{array}{c}\text { User's } \\
\text { competencies }\end{array}$ & $\begin{array}{c}\text { Provider's } \\
\text { technical } \\
\text { characteristics }\end{array}$ & $\begin{array}{c}\text { Provider's } \\
\text { competencies }\end{array}$ & $\begin{array}{c}\text { Environmental } \\
\text { demands }\end{array}$ & $\begin{array}{c}\text { Operational } \\
\text { capacity }\end{array}$ & $\begin{array}{c}\text { Strategic } \\
\text { decision- } \\
\text {-making }\end{array}$ \\
Acronym & CTE & CE & CTI & Cl & EA & CO & TDE \\
Items & 4 & 4 & 8 & 9 & 8 & 5 & 5 \\
$\begin{array}{l}\text { Cronbach's } \\
\text { alpha }\end{array}$ & 0.82 & 0.75 & 0.87 & 0.77 & 0.80 & 0.76 & 0.81 \\
\hline
\end{tabular}

Cronbach's alpha indicator was used to validate the constructs as a measure of internal reliability (FIELD, 2009; PASQUALI, 2010).

\section{RESULTS}

Typing and analyzing the data was performed on SPSS 15, where correlational analyses, comparing averages and multivariate analyses of covariance were also calculated, and Amos 7.0 used SEM for analysis. The database presented an acceptable level of confidence, as the frequencies for the research variables presented a valid total higher than $95 \%$ (FONSECA; MARTINS, 1996). Items for socio-demographic characterization and statistical control of the attributes that could directly interfere with the results were also prepared. The interviewees were distributed among the hierarchical levels: privates (18.8\%), corporals ( $12 \%)$, sergeants $(53 \%)$, sub-lieutenants $(5.2 \%)$, lieutenants $(0.2 \%)$ and others $(11 \%)$. The ages varied between 19 and 59 , with half of the respondents being over 41 years old. There was a predominance of men ( $80.1 \%)$ who were married $(71.5 \%)$, among the interviewees. Regarding the level of education, the participants were distributed between higher education $(67.7 \%)$, secondary education (18.9\%) and other levels of education (13.4\%). Half of them have 20 years of service or more at the PMDF.

The analysis and a discussion of the results are demonstrated in two stages. EFA and CFA are presented in the first stage, and were carried out to evaluate the extent to which the whole measurement model adjusts to the data, using the AMOS 7.0 program. Then, the SEM is presented according to the theoretical framework being tested to evaluate the relations between the individual variables in the model and adjustment of the structure as a whole. The determination of the results takes the average score into account (the higher the value, the more the respondents agree with the factor obtained). 


\subsection{EXPLORATORY AND CONFIRMATORY FACTOR ANALYSES}

EFA was carried out in accordance with the recommendations of Hair et al. (2009) who suggest that the number of factors where the self-value remains above 1 is observed. The aim was to investigate if the covariances or correlations of the set of variables observed could be explained in terms of a lower number of unobserved constructs, called latent variables or common factors, promoting data analysis (RIBAS; VIEIRA, 2011). The procedure adopted to extract the factor analysis factors was the Principal Factor Analysis (PFA) method, with direct oblimim rotation.

From a psychometric point of view, as Damásio (2012) observes, there is a gap in the consensus of acceptability of the indices obtained with the variance explained. In these terms, Figueiredo Filho and Silva Júnior (2010) adopt a factor solution of $40 \%$ as a tolerable limit in EFA for social sciences. However, for this study, the factor solution that explains at least $50 \%$ of the total variance was adopted, in accordance with Damásio (2012). For the SR scale, the solution presented three independent and responsible factors to explain $53.2 \%$ of the total variance and the solution indicated four independent and responsible factors to explain $50.2 \%$ of the total variance for ISSP. All the factors obtained a Cronbach's alpha above 0.70, as Pasquali (2010) recommends, indicating dependable (FIELD, 2009) and consistent (FORMIGA, 2011) scales (see Table 2) for exploratory studies. Then, CFAs were carried out through Maximum Likelihood - ML and path analysis, in order to examine the constructs, without relating them to the many variables (MARÔCO, 2010).

Therefore, two parameters were considered, each comprising two indicators. First, the Comparative Fit Index (CFI) and Root Mean Square Error of Approximation (RMSEA) to counter the completely independent model with the correlated one and to ratify which added variables improve the respective index estimate. The Standardized Root Mean Square Residual (SRMSR) indicators were then verified (to observe if the model was well adjusted) and chi-squared divided by degrees of freedom ( $\chi^{2} / G$.L) (for the sample to be considered large, $\chi^{2}$ was divided to adjust it) (MARÔCO, 2010).

Several of the items of some factors did not achieve the acceptable variance evaluated by Cronbach's alpha (it should remain over 0.5, according to Hair et al., 2009). Only the items for the users' technical characteristics factor were maintained. CE2 and CE4 were removed in the user's competencies factor; four items (CTI2, CTI5, CTI7 and CTI8) in the provider's technical characteristics factor and three items $(\mathrm{Cl} 5, \mathrm{Cl} 6$ and $\mathrm{Cl} 8)$ were removed in the provider's competencies. Confirmatory analysis of the ISSP scale presented SRMSR $=0.05, \mathrm{RMSEA}=0.05, \mathrm{CFI}=0.95$ and $\chi^{2} / \mathrm{G} . \mathrm{L}=2.7$.

All the saturations (Lambdas, $\lambda$ ) are within the expected interval $|0-1|$, meaning there are no estimation problems in the proposal (HAIR et al., 2009). Moreover, all are statistically different from zero $(\tau>1.96$ and $\rho<0.05)$ and Cronbach's alpha (Table 2$)$ is high. Having met the evaluation of dependability and structural validity of the first scale in the exploratory form and from SEM for both the analyses, the 16 items from the scale presented statistical confidence in their measurements, according to Djellal and Gallouj's (2012a) theoretical proposal. Thus, this scale could be described as ISSP indicators, measuring the provider and user's competencies and technical characteristics external and internal to the 
organization in community policing, guaranteed through the factor reliability and empirical evidence demonstrated here.

Observing the correlation between the factors, these presented independence and correlations within what is acceptable (under 60\%, according to BYRNE, 2011). The exception occurred between the user's competency and provider's competency factors, with an $88 \%$ correlation, meaning that the variables involved may be under the influence of the same factor (RIBAS; VIEIRA, 2011). However, even if there is still a high correlation (over $80 \%$ ), maintaining the factors in the model is desirable, since there is a robust theoretical indication displaying this division (MARÔCO, 2010) and this is the first exploratory study related to the proposed scale.

As in the previous scale, items from some of the factors did not achieve the acceptable variance, evaluated by Cronbach's alpha (HAIR et al., 2009). EA1, EA4, EA5, EA6 and EA8 were removed in the environmental demands (EA) factor; three items (CO1, CO2 and CO5) were removed in the operational capacities (CO) factor and two (TDE3 and TDE5) were removed in strategic decision-making (TDE). It was found that items TDE1 and TDE4 are correlated. Just like in the ISSP scale, the saturations are within the expected interval; they are statistically different from zero; and Cronbach's alpha is high (Table 2) (HAIR et al., 2009). Having met the presupposition of the evaluation of dependability and structural validity of the second scale in the exploratory form and from SEM for both the analyses, the eight items of the SR scale exhibited statistical reliability in their measurements, as expected in the theoretical proposal. The indices presented by the confirmatory factor analysis are SR$M S R=0.4$ RMSEA $=0.06, C F I=0.97$ and $\chi^{2} / G . L=2.5$, indicating an adequate adjustment of the items in their respective factors.

The various criteria used to define the number of factors to be removed [Kaiser, Cattel and parallel analysis according to Byrne (2011)] reinforce the solution presented according to Brown (2000). In the present scale (as in the previous one), of the items maintained, none had insufficient scores which could result in an inconsistent interpretation. The correlation of $74 \%$ presented by operational capacity and strategic decision-making is high and the relation between operational capacities and environmental demands is inversely proportional but not significant. The factors were then theoretically justified, since this is the procedure for correlations over 60\% (BYRNE, 2011). Consequently, this scale could be described as SR indicators (which evaluate the environmental demands, the relation between the levels and the functions, and the organization's operational capacities), supporting this research, together with the previous scale, with greater factor reliability and empirical evidence for its application and measurement in other military organizations and with different variables.

\subsection{TESTING THE STRUCTURAL MODEL}

In order to explain ISSP from SR, a structural recursive model was considered and tested, which represents the relationships described in Figure 1. In SEM, the relationships between the constructs were examined and following modifications to the error adjustments, an appropriate model was found, presenting the adjustment indices of SRMSR $=0.6 \mathrm{RM}$ $\mathrm{SEA}=0.06 \mathrm{CFI}=0.90$ and $\chi^{2} / \mathrm{G} . \mathrm{L}=3.3$, indicating appropriate accommodation of the path 
model. Some correlations are set at zero and theoretically justified (BYRNE, 2011). Figure 2 presents the integrated model of the relationship tested of SR as a predictor of ISPP.

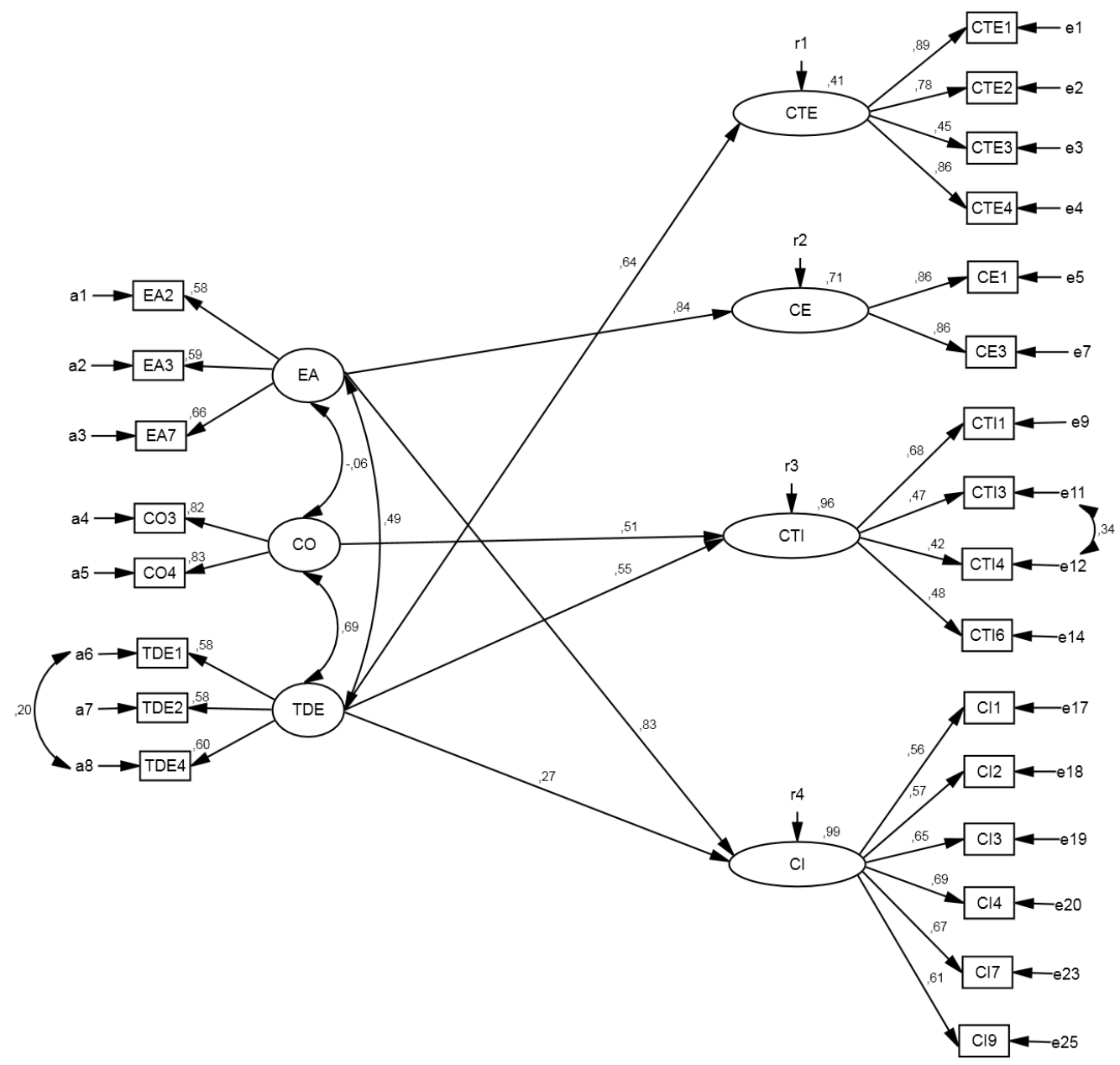

Figure 2 - Structural model.

As seen in Figure 2, the structural model indicates that environmental demands (EA) and strategic decision-making (TDE) are predictors of the provider's competency at 99\%, while strategic decision-making (TDE) and operational capacity (CO) are predictors of the provider's technical characteristics (CTI) at 96\%. User competency (CE) is predicted at a level of $71 \%$ for environmental demands (EA) and user's technical characteristics (CTE) at a level of $41 \%$ for strategic decision-making (TDE).

\subsection{ANALYSIS}

The results revealed reliability in the item-factor provision and its structure. When considering the ISSP scale, it is reflected around service processing which, according to 
Djellal and Gallouj (2012a, 2012b), comprises four vectors in the public context, in view of the fact that the user is the service producer with the provider in its concept. This condition gives reason to believe that $\mathrm{CP}$ does not only refer to inconsistent rhetoric but its processing at the CSSs presents indicators which include adding value both to the PMDF and the population served, which are inter-related, in order to improve public security in the place they share. This possibility was proven in so far that it sought to elucidate, at the same level of analysis; in other words, from the explanation of the operational level of the PMDF that works at the CSSs, the CP service process through expertise and the devices used by providers and users to provide the service. When an alteration in any of these characteristics which form the service (or all of them) is found, we can consider that value was added to the final result. Along these lines, a high correlation between user competency (CE) and the provider's competencies (Cl) can be observed (Figure 2).

This results are justified for due to the need, both by the CSS police and the popolation served by $\mathrm{CP}$, to present and develop related competencies, in order to operationalize the service, representing a close relationship of the co-production required for its execution. In this regard, authors generally suggest that the police are resistant to changes to their skills and attitudes (CHALOM et al., 2001; PONCIONI, 2013), while the population establishes presuppositions of tension with police organizations that include distrust and fear (MESQUITA NETO, 2004; OLIVEIRA JÚNIOR; SILVA, 2010; ROLIM, 2007), among others. However, it was noticed that the interviewees had a conception of a policing IS constructed from the relationship between the parties, due to the CSSs, as Gallouj (2002) advocates. For Cruz and Barbosa (2002b) and Poncioni (2013), this behavior is common in organizations that work with public security, as environmental pressures induce them to enhance their competencies in order to improve their operations. This result is confirmed by other studies on CP from the standpoint of the simultaneous mobilization of competencies to operationalize the service (such as in: BAYLEY; SKOLNICK, 2002; BENGOCHEA et al., 2004).

On the SR scale, the phenomenon was addressed at the PMDF and it was detected that the operational capacities (CO) related to the CSSs and integration of the levels and positions in decision-making on these structures (TDE) present a high correlation. This finding is justified on account of the hierarchical and bureaucratic structure in which the PMDF is classified (CRUZ; BARBOSA, 2002a; OLIVEIRA, 2011). Since strategic decision-making results in fluidity of information and participation at the operational level and this does not take place, in accordance with a correlation of $74 \%$ between the constructs strategic decision-making (TDE) and operational capacity (CO), nor are operational capacities met, with a dissonance between what is necessary and delivered by the strategic to the operational level. Environmental demands (EA) do not reflect the stations' operational capacities; in other words, the CSS structure does not respect local community demands. Other authors who have researched $\mathrm{CP}$ of police organizations in Brazil have indicated similar results. In Mesquita Neto's (2004) study reporting the CP experience in São Paulo, dismantling the police, in terms of equipment and structure, was found and correlated, in symmetry with the strategic positioning of the organization studied. For Rolim (2007), the innovation perceived in $\mathrm{CP}$ is not the result of decisions made at the strategic level of the corporations (occupied by political police officers) nor the physical structure at the stations, decided by people who merely assume the operational needs of the CP service. 
This previously developed perception provides reflections on the correlation between strategic decision-making (TDE) and user's technical characteristics (CTE). It is observed that the fact of having no fluidity of information between the operational and strategic levels results in a lack of operational capacity (correlation of 0.69 between TDE and CO in Figure 2). Therefore, the fact that the strategic level does not meet required operational demands generates a perception of a lack of technical apparatus from the population, which the respondents evaluate. Consequently, the community does not dispose of the devices, procedures and technologies used for their security; in other words, a low score in strategic decision-making is reflected in a population which acknowledges the corporation's lack of operational resources and therefore does not eliminate their technical security mechanisms. Internal operating conditions (the structure) influence the methods and technologies used to operationalize the service provision process as much as strategic decision-making, since the way the service is operationalized is in line with the dictates of the corporation.

According to the interviewees, environmental demands (EA) predict the competencies obtained by the police officers to execute their service $(\mathrm{Cl})$; in other words, competencies were added, due to the environmental context. This result is in contrast with the results obtained in another study, which describes that the population confirms there is little community interaction with the military police (TCDF, 2009). This discrepancy between the results could be explored in future studies, in which the influence of the variables of a distinct context between the two results is evaluated, particularly relating to the organization's arguments that it disagrees with this result, alleging that the research was not carried out in the CSSs' area of coverage and its aim was not to evaluate the CP model (UAG, 2010). The police officers' internal competencies are more influenced by environmental demands, the media and the population, while perception of the organization's strategic level has a lower influence than the population desires, naturally respecting the characteristic of the CSS, which exercises the function of being more aligned to the environment in which it is placed than the corporation. In a previous study, the capacity of environmental demands of predicting external competencies was confirmed in interviews and documentary analysis as, in the police's point of view, the knowledge acquired is in line with these demands. Examples of this are participation at talks, courses and socio-educational activities at the CSSs, in order to inform and prepare the population. Thus, it is recognized that the SR factor and its items predict ISSP, both in exploratory and confirmatory analysis.

\section{CONCLUSIONS}

The aim of this article was to demonstrate the influence that SR may have on ISSP, taking the PMDF CSSs as the case for analysis. Thus, a first exploratory contribution of a model of the relation between SR and IS at a Brazilian military police organization was tested with the construction of two scales. Evidence of exploratory and confirmatory scale validity was presented, emphasizing the theoretical contribution to the field of strategy with this implication, specifically at a public organization. The research results show that the structural relations postulated between the variables are generally corroborated by global sample analyses. It was noted that the interviewees had a view of IS in policing constructed from the relationship of the parties due to the CSSs. As in Menelau et al. (2015), this finding 
shows that the CSSs are an ISSP, where it is observed that solving a problem is linked to the population's interaction with the PMDF police in a multiple relation of joint production, comprising the human, structural and operational characteristics of the service, as Gallouj (1997; 2002) establishes.

Second, it is also argued that with the SR found, although not all the presuppositions have been met, it builds on the efforts of developing the CP service provided at the CSSs, expanding the meaning of innovation at the PMDF and leading to increased content and receptivity. Similar findings, in which SR was a potential driving force to enlarge a small action, can be found in Mann (2002). However, the fact that the organization remained linked to other strategy paradigms but specifically on the dependence of decision-making of an elite group at the top of the PMDF hierarchy, leads to a state of internal strategic dissonance (BROWN, 1998; 2000), showing a discrepancy between strategic intention and operational capacities (BURGELMAN; GROVE, 2012; PRAHALAD; HAMEL, 2012). However, this does not constitute a barrier that limits innovation.

It is important to highlight the uniqueness of this research, both in the magnitude of data collection at a PM and the proposal of the relationship between SR and IS, as the main empirical and theoretical contributions. Although evidence of scale validation was obtained and can explain both SR and innovation of the police service, a number of limits should be highlighted: it is a restricted study on a single organization - the Federal District Military Police, which does not allow for a generalization regarding other military police services and similar organizations. It would be interesting to perform research on individual CP users, on representative samples of the Military Police in other states, and in other organizations and organizational contexts for both scales. A further study could be carried out in intercultural and transcultural terms, in order to evaluate the structure and consistency of these indicators and their predictions in police organizations in different countries, comparing the results with the Brazilian studies.

\section{REFERENCES}

ADORNO, S.; DIAS, C. Monopólio estatal da violência. In: LIMA, R. S.; RATTON, J. L.; AZEVEDO, R. G. (Org.). Crime, polícia e justiça no Brasil. São Paulo: Contexto, p. 187-197, 2014.

BARDIN, L. Análise de conteúdo. Lisbon: Edições 70, 2009.

BAYLEY, D.H.; SKOLNICK, J.H. Nova polícia: Inovações nas polícias de seis cidades norte-americanas. 2 ed., São Paulo: Edusp, 2002.

BEATO FILHO, C.C. Políticas públicas de segurança e a questão policial. São Paulo em Perspectiva, 13(4), p. 13-27, 1999.

BENGOCHEA, J.L.P et al. A transição de uma polícia de controle para uma polícia cidadã. São Paulo em Perspectiva, 18(1), p. 119-131, 2004.

BONDARUK, R.L.; SOUZA, C.A. Polícia comunitária: Polícia cidadã para um povo cidadão. 4 ed., Curitiba: Comunicare, 2012. 
BREWER, J.; HUNTER, A. Foundations of multimethod research: Synthesizing styles. Thousand Oaks: London: Sage, 2006.

BRODEUR, J. P. Como reconhecer um bom policiamento. São Paulo: Edusp, 2002.

BROWN, S. Manufacturing strategy, manufacturing seniority and plant performance in quality. International Journal of Operations \& Production Management, 18(6), p. 24-39, 1998.

. Manufacturing the future: Strategic resonance for enlightened manufacturing. London: Prentice Hall, 2000.

. Strategic reconfiguration-manufacturing's key role in innovation. Production and Inventory Management Journal, Third/Fourth Quarter, p. 9-16, 2001.

BROWN, S.; BESSANT, J. The manufacturing strategy-capabilities links in mass customisation and agile manufacturing - an exploratory study. International Journal of Operations \& Production Management, 23(7), p. 707-730, 2003.

BROWN, S.; BLACKMON, K. Aligning manufacturing strategy and business-level competitive strategy in new competitive environments: The case for strategic resonance. Journal of Management Studies, 42(4), p. 793-815, 2005.

BROWN, S.; COUSINS, P. D. Supply and operations: Parallel paths and integrated strategies. British Journal of Management, 15, p. 303-320, 2004.

BROWN, S.; FAI, F. Strategic resonance between technological and organisational capabilities in the innovation process within firms. Technovation, 26, p. 60-75, 2006.

BURGELMAN, R. A.; GROVE, A. S. Dissonância estratégica. In: BURGELMAN, R.A.; CHRISTENSEN, C. M.; WHEELWRIGTH, S. C. Gestão estratégica da tecnologia e da inovação: Conceitos e soluções. 5 ed., Porto Alegre: AMGH, p. 277-289, 2012.

BYRNE, B. Structural equation modeling with EQS: Basic concepts, applications and programming. Washington: SAGE. 2011.

CARDOSO, M. Obstáculos para o sucesso de projetos de policiamento comunitário. In: CONGRESSO LUSO AFRO-BRASILEIRO DE CIÊNCIAS SOCIAIS, 11. Salvador, 2011. Anais... Salvador: UFBA. 2011.

CARLBORG, P.; KINDSTRÖM, D.; KOWALKOWSKI, C. The evolution of service innovation research: A critical review and synthesis. Service Industries Journal, 34(5), p. 373-398, 2014.

CHALOM, M. et al. Urban safety and good governance: The role of the police. Safer Cities Programme/International Centre for the Prevention of Crime: Nairobi, 2001.

CHOI, J. N.; CHANG, J. Y. Innovation implementation in the public sector: An integration of institutional and collective dynamics. Journal of Applied Psychology, 94(1), p. 245-253, 2009.

CHURCHILL, G.A. Marketing research: Methodological foundation. 7 ed., Orlando: Dryden Press, 1999. 
COELHO, E.C. A administração do sistema de justiça criminal. Dados, 29(1), p. 61-81, 1986.

COUSINS, P.; STANWIX, E. It's only a matter of confidence! A comparison of relationship management between Japanese and UK non-Japanese owned vehicle manufacturers. International Journal of Operations \& Production Management, 21(9/10), p. 1160-1179, 2001.

CRAIG, S. G.; HEIKKILA, E. J. Urban safety in Vancouver: Allocation and production of a congestible public good. The Canadian Journal of Economics/Revue Canadienne d'Economique, 22(4), p. 867-884, 1989.

CRUZ, M. V. G.; BARBOSA, A. C. Q. Uma abordagem organizacional na segurança pública: Notas para discussão. In: ENCONTRO DE ESTUDOS ORGANIZACIONAIS, Recife, 2002. Anais... Refice: ENEO, 2002a.

- Modelos de policiamento para a gestão da segurança pública. In: ENCONTRO DE ESTUDOS ORGANIZACIONAIS, Recife, 2002. Anais... Recife: ENEO, 2002b.

DAMÁSIO, B. F. Uso da análise fatorial explicatória em psicologia. Avaliação Psicológica, 11(2), p. 213-228, 2012.

DE VRIES, H. A.; BEKKERS, V. J. J. M.; TUMMERS, L.G. Innovation in the Public Sector: A systematic review and future research agenda. Speyer: EGPA conference, 2014.

DJELLAL, F.; GALLOUJ, F. L'innovation dans les services publics. Revue Française D'économie, 2(XXVII), p. 97-142, 2012a.

. Two decades of research on innovation in services: which place for public services? In: INTERNATIONAL EIBURS-TAIPS CONFERENCE ON: INNOVATION IN THE PUBLIC SECTOR AND PUBLIC SERVICES,1st., 2012. Anais... Urbino: Italie, 2012b.

FIELD, A. Descobrindo a estatística usando o SPSS. 2 ed. Porto Alegre: Artmed, 2009.

FIGUEIREDO FILHO, D.B.; SILVA JÚNIOR, J.A. Visão além do alcance: Uma introdução à análise fatorial. Opinião Pública, 16(1), p. 160-185, 2010.

FONSECA, J. S.; MARTINS, G. A. Curso de estatística. 6 ed. São Paulo: Atlas, 1996.

FORMIGA, N. S. Valoração da família e condutas desviantes: Testagem de um modelo teórico. Psico, 42(3), p. 383-392, 2011.

GAINES, L. K.; TROJANOWICZ, R.; KAPPELER, V.K. Community policing: A contemporary perspective. Cincinnati: Anderson Publishing, 2009.

GALLOUJ, F. Cycles économiques et innovations de service: À la lumière de la pensée schumpéterienne. Revue Française d'Économie, Programme National Persée, 9(4), p. 169213, 1994.

. Towards a neo-Schumpeterian theory of innovation in services? Science and Public Policy, 24(6), p. 405-420, 1997.

. Knowledge-intensive business services: Processing knowledge and producing innovation. In: GADREY, J.; GALLOUJ, F. (eds.). Productivity, innovation and knowledge in 
services: New economic \& socio-economic approaches Great Britain: Edward Elgar Publishing, 2002, p. 256-284.

GALLOUJ, F. Economia da inovação: Um balanço dos debates recentes. In: BERNARDES, R.; ANDREASSI, T. (orgs.). Inovação em serviços intensivos em conhecimento. São Paulo: Saraiva, 2007, p. 3-27.

GALLOUJ, F.; SAVONA, M. Towards a theory of innovation in services: A state of the art. In GALLOUJ, F.; DJELLAL, F. The handbook of innovation in services: A multi-disciplinary perspective. UK/USA: Edward Elgar, 2010, p. 27-48.

GALLOUJ, F.; WEINSTEIN, O. Innovation in services. Research Policy, 26(4-5), p. 537556, 1997.

GALLOUJ, F.; WINDRUM, P. Services and services innovation. Journal of Evolutionary Economics, 19(2), p. 141-148, 2009.

GOVERNO DO DISTRITO FEDERAL. Portaria n. 30, de 28 de fevereiro de 2005. Diretriz de segurança comunitária: estabelece a atuação específica dos órgãos, unidades e Conselhos de que trata o Decreto $n^{0}$ 24.316, de 23 de dezembro de 2003. Governo do Distrito Federal, Secretaria de Segurança Pública e Defesa Social, Brasília, DF. 2005.

HAIR, J.F. et al. Análise multivariada de dados. 6 ed. Porto Alegre: Bookman, 2009.

LEONARD-BARTON, D. Swedish entrepreneurs in manufacturing and their sources of information. Centre for Policy Application, MIT: Boston, 1982.

LIMA, D. H; VARGAS, E. R. Estudos internacionais sobre inovação no setor público: Como a teoria da inovação em serviços pode contribuir?. Revista Administração Pública, 46(2), p. 385-401, 2012.

LIMA, R.S.; RATTON, J.L.; AZEVEDO, R.G. Introdução. In: LIMA, R.S.; RATTON, J.L.; AZEVEDO, R.G. (orgs.). Crime, polícia e justiça no Brasil. São Paulo: Contexto, 2014, p. 13-15.

MALHOTRA, N. K. Pesquisa de Marketing: Uma orientação aplicada. 3 ed. Porto Alegre: Bookman, 2001.

MANN, D. Manufacturing technology evolution trends. Integrated Manufacturing Systems, 13(2), p. 86-90, 2002.

MARÔCO, J. P. Análise de equações estruturais: Fundamentos teóricos, software e aplicações. Pêro Pinheiro: Report Number, 2010.

MARX, G. T. The interweaving of public and private police undercover work. In: SHEARING, C.D.; STENNING, P.C. (eds.). Private Policing. Newbury Park, California: Sage Publications, 1987.

MCKENNA, P. F. Tiered policing: An alternative model of police service delivery. CPC Discussion Paper Series. Canadian Police College, p. 1-19, 2014.

MENELAU, S. et al. Facilitadores e barreiras à inovação em serviço nos Postos Comunitários de Segurança do Distrito Federal. In: ENCONTRO ANPAD, 39, Belo Horizonte, 2015.

Anais... Belo Horizonte: ANPAD, 2015. 
MESQUITA NETO, P. Policiamento comunitário e prevenção do crime: A visão dos coronéis da Polícia Militar. São Paulo em Perspectiva, 18(1), p. 103-110, 2004.

MINTZBERG, H.; LAMPEL, J.; GHOSHAL, S. 0 processo da estratégia. 4 ed. Porto Alegre: Bookman, 2006.

MULGAN, G.; ALBURY, D. Innovation in the public sector, Prime Minister's strategy Unit. v. 1.9. London: Cabinet Office. 2003 (UK cabinet office discussion paper).

NAQSHBANDI, M.; KAUR, S. A study of organizational citizenship behaviours, organizational structures and open innovation. International Journal of Business and Social Science, 2(6), p. 182-19, 2011.

NARANJO-GIL, D. The influence of environmental and organizational factors on innovation adoptions: Consequences for performance in public sector organizations. Technovation, 29, p. 810-818, 2009.

OECD. Manual de Oslo: Diretrizes para coleta e interpretação de dados sobre inovação. 3 ed. FINEP, 2005.

OLIVEIRA, P. A atividade de inteligência na Polícia Militar do Distrito Federal como orientadora do emprego do policiamento ostensivo para a Copa do Mundo de 2014. Monograph presented to the Department of Studies at the War College, Advanced Studies Course on Policy and Strategy, 2011.

OLIVEIRA JÚNIOR, A.; SILVA, E. B. As polícias estaduais brasileiras: O desafio da reforma. In: IPEA. Brasil em desenvolvimento: Estado, planejamento e política pública. v. 3, Brasília: IPEA, p. 628-646, 2010.

PMDF. Plano de Ação - Postos Comunitários de Segurança. Brasília: Federal District Military Police, 2007.

PASQUALI, L. Instrumentação psicológica: Fundamentos e práticas. Porto Alegre: Artmed, 2010.

PONCIONI, P. 0 caso da educação policial no Brasil. Civitas, 13(1), p. 48-55, 2013.

PRAHALAD, C.K.; HAMEL, G. A competência central da empresa. In: BURGELMAN, R.A.; CHRISTENSEN, C.M.; WHEELWRIGTH, S.C. Gestão estratégica da tecnologia e da inovação: Conceitos e soluções. 5 ed., p. 34-45, Porto Alegre: AMGH, 2012.

RIBAS, J. R.; VIEIRA, P. R. C. Análise multivariada com uso do SPSS. Rio de Janeiro: Ciência Moderna, 2011.

RIBEIRO, L. Policiamento comunitário. In: LIMA, R. S.; RATTON, J. L.; AZEVEDO, R. G. (orgs.). Crime, polícia e justiça no Brasil. São Paulo: Contexto, 2014, p. 527-538.

ROBERTSON, D. Public and private policing: Issues and options for collaboration within Australia. In: Conference Partnerships in Crime Prevention, Australian Institute of Criminology and the National Campaign Against Violence and Crime, Hobart, p. 25-27, 1998.

ROLIM, M. Caminhos para a inovação em segurança pública no Brasil. Revista Brasileira de Segurança Pública, 1(1), p. 32-47. 2007. 
SAPORI, L. F. A inserção da polícia na Justiça Criminal brasileira: Os percalços de um sistema fracamente articulado. In: FREITAS, I.; MARIANO, B.D. (orgs.). Polícia: Desafio da democracia brasileira. Porto Alegre: Corag, 2002.

SCHUMPETER, J. A. Teoria do desenvolvimento econômico: Uma investigação sobre lucros, capital, crédito, juro e o ciclo econômico. 3 ed. São Paulo: Nova Cultural, 1982.

SILVEIRA, A.M. A prevenção do crime e segurança comunitária. In: LIMA, R.S.; RATTON, J.L.; AZEVEDO, R.G. (orgs.). Crime, polícia e justiça no Brasil. São Paulo: Contexto. 2014, p. 539-546.

SLACK, N.; LEWIS, M. Estratégia de operações. 2 ed., Porto Alegre: Bookman, 2011.

SPARROW, M. K. Managing the boundary between public and private policing. Washington, DC: U.S. Department of Justice, National Institute of Justice. New Perspectives in Policing Bulletin., september 2014.

SPETIC, W.; MARQUEZ, P.; KOZAK, R. Critical areas and entry points for sustainability-related strategies in the sugarcane-based ethanol industry of Brazil. Business Strategy and the Environment, 21, p. 370-386, 2012.

TABACHNICK, B.G.; FIDELL, L.S. Using multivariate analysis. Needham Heights: Allyn \& Bacon, 2007.

TCDF. Auditoria operacional no sistema de segurança pública do Distrito Federal. Federal District: Federal District Court of Auditors, 2009.

UAG. Ofício n. 148/2010. Federal District: Department of Public Safety (SSPDF). General Administration Unit. 2010.

UNODC. Brazil and the Southern Cone. Gestão e governança da segurança pública no Distrito Federal e entorno. United Nations Office on Drugs and Crime (UNODC), 2011.

VARGAS, E.R. et al. A pesquisa sobre inovação em serviços no Brasil: Estágio atual, desafios e perspectivas. Revista de Empreendedorismo e Gestão de Pequenas Empresas, 2(1), 2013, p. 3-21.

WAGNER III, J. A.; HOLLENBECK, J. A. Comportamento organizacional: Criando vantagem competitiva. 3 ed. São Paulo: Saraiva, 2012.

WANG, J.; CAO, D. Relationships between two approaches for planning manufacturing strategy: A strategic approach and a paradigmatic approach. Int. J. Production Economics, 115, p. 349-361, 2008.

Submission date: 09/13/2016.

Approval date: 12/14/2017.

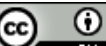

Creative Commons Atribuição 4.0 Internacional

Note: you can find this paper in Portuguese at http://www.revistaoes.ufba.br. 